\title{
Analisis Faktor-Faktor yang Mempengaruhi Minat Menabung di Bank Syariah pada Masyarakat Kabupaten Banyumas
}

\author{
Sodik Dwi Purnomo, Heru Cahyo, Siti Ainul Mukharomah \\ Fakultas Ekonomika dan Bisnis, Universitas Wijayakusuma Purwokerto \\ Correspondence e-mail: sodikdwipurnomo@yahoo.com
}

\begin{abstract}
This study aims to analyze the effect of financial literacy, trust, location, income, and perception of profit sharing on interest in saving in Islamic banks. This type of research is quantitative. The sampling technique was simple random sampling and a sample of 100 respondents. The method of analysis used multiple linear regression. The results showed that financial literacy and location did not affect the interest in saving in Islamic banks in the people of Banyumas Regency. trust, income and perception of profit sharing have a positive and significant effect on the interest in saving in Islamic banks in the people of Banyumas Regency. the need to improve the provision of information about Islamic banks such as Islamic principles and products in Islamic banks, so that public interest in saving in Islamic banks will increase.
\end{abstract}

Keywords: Trust; Financial literacy; Location; Interest in saving; Perception of profit sharing

\section{Pendahuluan}

Aktivitas menyisihkan sebagian uang dari hasil pendapatan atau yang lebih akrab disebut menabung sudah dikenal sebagai kegiatan yang positif di kalangan masyarakat Indonesia. Penanaman dan budaya menabung sudah diajarkan sejak di bangku sekolah agar nantinya dapat menjadi kebiasaan yang diteruskan di masa depan dan dapat berpikir antisipatif terhadap keadaan yang tidak terduga seperti inflasi. Inflasi yakni kenaikan dengan terus menerus pada harga jasa maupun barang dalam jangka waktu tertentu. Dengan menabung, daya beli masyarakat yang tinggi akan menurun sehingga laju inflasi dapat dikendalikan. Inflasi pun berdampak pada tabungan domestik, dimana adapun solusi untuk menangani kondisi itu yakni dengan menggalakkan kegiatan menabung (Marlina dan Iskandar, 2019). Dalam melakukan kegiatan menabung, masyarakat dapat menggunakan jasa perbankan untuk menyimpan uang yang dimilikinya. Peran dari bank besar sekali untuk kemajuan serta perkembangan dari sebuah negara. Bank pada operasional usahanya bukan sebatas mengutamakan laba, tetapi juga mengarah untuk meningkatkan taraf hidupnya penduduk. Hal ini tercantum pada Pasal 1 butir 2 UU No. 21 Tahun 2008 tentang Perbankan Syariah.

Dalam perkembangannya, sektor perbankan tidak hanya terdiri dari bank konvensional saja. Perbankan syariah juga hadir guna melayani kebutuhan perbankan masyarakat yang membutuhkan layanan bank secara islami. Indonesia yakni sebuah negara yang mempunyai warga beragama Islam paling banyak di dunia. Kondisi itu menjadi penyebab dari perkembangan perbankan syariah di Indonesia yang pesat. Perekonomian bisa dengan baik berjalan serta bisa dengan lancar berkembang bila perbankan pada daerah tersebut berjalan dengan baik. Misalnya perbankan syariah yang menyajikan beragam produk pembiayaan maupun tabungan dimana bisa menyokong lancarnya perekonomian masyarakat yang selanjutnya mampu berpengaruh pada kemakmuran serta dengan tidak langsung berkontribusi positif (Amdar, 2016). Keberadaan bank syariah mendapati pertumbuhan signifikan di Indonesia selepas terdapatnya UU No. 10 Tahun 1998 tentang perubahan untuk UU No. 7 Tahun 1992 tentang Perbankan. Adapun pada UU yang memperoleh perubahan itu dengan jelas disebutkan bahwasanya Bank Perkreditan Rakyat maupun Bank Umum beroperasi secara konvensional serta berdasar pada prinsip syariah. Hadirnya UU itu dikuatkan oleh terbitnya UU No. 21 tahun 2008 tentang Perbankan Syariah dimana dengan tegas memberikan pengakuan pada bank syariah serta membedakannya pada mekanisme bank konvensional (Alhamid, 2019). Adapun dibalik pertumbuhan regulasi dari bank syariah, terekam suatu fakta bahwasanya kemunculan bank syariah merupakan jawaban dari keinginan penduduk Indonesia akan perbankan yang terbebas dari bunga. Akan tetapi setelah dinyatakan legal untuk melaksanakan operasionalnya di Indonesia mulai tahun 1992, bank syariah tidak berkembang dengan pesat. Setelah itu timbul fakta terbaru yang mengejutkan dimana bank syariah merupakan lembaga finansial yang tetap stabil serta sehat ketika kurs runtuh. Hal tersebut terbukti melalui kesuksesan Bank Muamalat Indonesia yang berhasil melalui krisis moneter tahun 1998 dan semakin memperlihatkan peningkatan kinerjanya dengan tidak memperoleh sepersen pun pertolongan dari pemerintahan dalam krisis keuangan tahun 2008 (Alhamid, 2019). 
Sodik Dwi Purnomo et al., Analisis Faktor-Faktor yang Mempengaruhi Minat Menabung di Bank Syariah pada Masyarakat Kabupaten Banyumas

Tabel 1

Persebaran Jaringan Kantor Perbankan Syariah di Indonesia (Dalam Unit)

\begin{tabular}{lrrrrr}
\hline \multicolumn{1}{c}{ Indikator } & \multicolumn{1}{c}{2016} & 2017 & 2018 & 2019 & 2020 \\
\hline Bank Umum Syariah & 1.869 & 1.825 & 1.875 & 1.919 & 2.034 \\
Unit Usaha Syariah & 332 & 344 & 354 & 381 & 392 \\
BPR Syariah & 453 & 441 & 495 & 617 & 627 \\
Total Kantor & 2.654 & 2.610 & 2.724 & 2.917 & 3.053 \\
\hline Sur & & &
\end{tabular}

Sumber : Otoritas Jasa Keuangan (OJK), 2021

Bank syariah meliputi Unit Usaha Syariah (UUS), Bank Umum Syariah (BUS), serta Bank Pengkreditan Rakyat Syariah (BPRS). Berdasarkan pada tabel 1, diperlihatkan persebaran jaringan kantor bank syariah di Indonesia dari tahun 2016-2020 paling banyak berbentuk BUS, sementara UUS terbilang relatif sedikit jumlahnya. Persebaran dari jaringan kantor bank ini setiap tahun mendapati kenaikan. Berarti bisa dikatakan bahwasanya bank syariah berkembang dengan positif melalui eksistensinya yang bisa dengan baik diterima penduduk Indonesia.

Tabel 2.

Jumlah Nasabah Dana Pihak Ketiga Bank Syariah di Indonesia (Dalam Satuan Rekening)

\begin{tabular}{|c|r|r|c|}
\hline Tahun & Jumlah Nasabah Bank Umum Syraiah & Jumlah Nasabah Unit Usaha Syariah & Total \\
\hline 2016 & 15.488 .398 & 3.032 .693 & 18.521 .091 \\
\hline 2017 & 17.955 .556 & 3.736 .907 & 21.692 .463 \\
\hline 2018 & 19.996 .197 & 4.338 .359 & 24.334 .556 \\
\hline 2019 & 22.120 .609 & 4.894 .997 & 27.015 .606 \\
\hline 2020 & 25.195 .687 & 5.341 .698 & 30.537 .385 \\
\hline
\end{tabular}

Sumber : Otoritas Jasa Keuangan (OJK), 2021

Berdasarkan pada data tersebut, bisa diamati bahwasanya jumlah nasabah dana pihak ketiga bank syariah mendapati kenaikan tiap tahun. Kenaikan jumlah nasabah ini membuktikan bahwa minat masyarakat untuk menjadi nasabah bank syariah terus bertambah tiap tahunnya. Presentase peningkatan nasabah dari tahun 2016 ke tahun 2017 adalah 17\% serta pada tahun 2018 meningkat sejumlah 12\% dari tahun sebelumnya. Kemudian, di tahun 2019 naik sebesar $11 \%$ dari tahun sebelumnya serta di tahun 2020 naik 11,5\% dari tahun sebelumnya. Meskipun jumlah nasabah bank syariah ini mendapati kenaikan tiap tahun, hal tersebut tidak sebanding pada jumlah nasabah bank konvensional di Indonesia di tahun 2020 yaitu sejumlah 76.122.714 rekening (www.ojk.co.id, 2021). Hal tersebut membuktikan bahwa minat dari masyarakat Indonesia untuk menabung pada perbankan syariah terbilang kurang dibandingkan pada minat menabung masyarakat di bank konvensional.

Tabel 3.

Jumlah Nasabah Dana Pihak Ketiga Bank Konvensional dan Bank Syariah di Kabupaten Banyumas

\begin{tabular}{lrr}
\hline Tahun & Jumlah Nasabah Bank Konvensional & Jumlah Nasabah Bank Syariah \\
\hline 2016 & 1.583 .937 & 169.541 \\
2017 & 1.916 .749 & 196.588 \\
2018 & 2.219 .155 & 218.293 \\
2019 & 2.361 .571 & 2.113 .337 \\
2020 & 2.753 .804 & 255.371 \\
\hline
\end{tabular}

Sumber : Otoritas Jasa Keuangan (OJK), 2021

Tabel 3, didapati bahwasanya jumlah nasabah bank syariah di lima tahun terakhir masih lebih rendah dibandingkan dengan bank konvensional. Jumlahnya nasabah bank syariah di tahun 2020 hanya sejumlah 294.680 dari total jumlah nasabah bank di Kabupaten Banyumas yaitu 3.048.484 rekening. Hal ini membuktikan bahwa minat masyarakat Kabupaten Banyumas untuk menabung pada bank syariah terbilang sangat kurang melalui persentase hanya 10 persen dari total jumlah nasabah bank di Kabupaten Banyumas. Berdasar pada latar belakang permasalahan di atas, peneliti akan meneliti penyebab rendahnya minat menabung di bank syariah pada masyarakat Kabupaten Banyumas melalui beberapa faktor yaitu literasi keuangan, kepercayaan, lokasi, pendapatan, dan presepsi bagi hasil. Literasi keuangan adalah pengetahuan untuk mengelola keuangan. Sedangkan inklusi keuangan adalah keterlibatan seseorang dalam pemanfaatan produk dan jasa keuangan. Indeks literasi keuangan bank syariah baru meraih $8,11 \%$ sementara untuk indeks inklusi hanya $11 \%$. Tingkatan yang rendah ini diakibatkan oleh kantor cabang dari bank syariah dimana jumlahnya tentu kalah dari bank konvensional. Perbedaan dari jaringan itu pun tidak terlepas dari umur dari perbankan, dimana perbankan syariah tentunya bisa dikatakan lebih muda. Adapun bank konvensional paling tua yang berumur 125 tahun, sementara untuk bank syariah yakni 28 tahun (Rahma, 2020). Perbankan mempunyai sejumlah sarana yang perlu diraih, seperti memberi informasi terkait keuangan yang betul-betul 
diperlukan nasabah (Kasmir, 2008). Realitanya masyarakat lebih terbiasa mempergunakan jasa perbankan konvensional, mereka berasumsi bahwasanya menabung pada bank konvensional maupun syariah tidak berbeda dikarenakan pemahaman serta sosialisasi yang kurang terkait operasional bank syariah. Lebih banyaknya kemunculan perbankan konvensional dibandingkan perbankan syariah pun berdampak pada rendahnya minat untuk menabung di perbankan syariah oleh masyarakat. Minat termasuk aspek yang esensial untuk dunia perbankan, dimana merupakan kecenderungan dengan sifat menetap dalam mengenang serta memperhatikan suatu kegiatan.

Minat menabung masyarakat pada bank syariah dipengaruhi oleh sejumlah faktor. Adapun berdasarkan keterangan sebelumnya diketahui bahwa literasi keuangan yang dimiliki oleh bank syariah tergolong kurang. Berdasar pada sumber dari OJK (Otoritas Jasa Keuangan), salah satu faktor intern penyebab rendahnya minat terhadap bank syariah adalah karena level literasi terkait keuangan syariah masyarakat yang terbilang rendah. Literasi keuangan disebut juga sebagai melek keuangan (Fauzi, 2020). Hal itu selaras pada penelitian dari Fauzi (2020) dimana menjelaskan, literasi keuangan mempengaruhi minat menabung di bank syariah secara positif. Sementara itu, hasil penelitian Hakim (2020) menunjukkan, literasi keuangan tidak mempengaruhi keputusan membuka rekening bank syariah. Dengan demikian semakin tinggi pemahaman literasi keuangan belum pasti mampu memperbesar peluang keputusan untuk membuka rekening di bank syariah. Kondisi tersebut dikarenakan responden di Indonesia tidak mempertimbangkan literasi keuangan selaku faktor pokok penentu keputusan menabung di bank syariah. Terlepas dari kelemahan yang dimiliki oleh perbankan syariah dari segi literasi keuangan, kelebihan yang dimiliki perbankan syariah ialah menerapkan sistem keuangan secara islami sehingga dapat mempengaruhi kepercayaan nasabah terutama masyarakat muslim, dimana tanpa adanya kepercayaan dari nasabah tentunya perbankan tak akan bisa melaksanakan aktivitasnya secara baik. Sehingga bisa dikatakan kepercayaan dari nasabah sangatlah penting untuk perbankan. Bila kepercayaan diantara nasabah serta bank telah tercipta, upaya dalam melangsungkan kerja sama bisa dilaksanakan dengan lebih mudah dimana tentunya bagi seluruh pihak akan menguntungkan. Hal ini sejalan dengan temuan Andriani (2019) yang menunjukkan bahwa kepercayaan nasabah terhadap perbankan syariah berpengaruh pada minat untuk menyimpan uang serta bertransaksi di bank syariah. Kondisi itu terjadi karena melalui terdapatnya kepercayaan dari nasabah yang tinggi, ia akan lebih yakin bahwasanya perbankan dapat mengemban tanggung jawab terkait tugasnya. Bila nasabah yakin serta percaya pada kinerjanya perbankan dalam pengelolaan dana nasabah, artinya minat dari nasabah untuk melaksanakan transaksi serta menitipkan dana pada bank akan mengalami peningkatan.

Selain itu lokasi juga berperan penting terhadap bertambahnya nasabah. Jarak diantara lokasi bank pada tempat tinggal nasabah serta lokasi yang bisa dijangkau kendaraan dengan mudah termasuk faktor yang memberikan pengaruh pada nasabah untuk menabung di bank. Pemilihan lokasi sangat penting karena berakibat meningkatnya biaya yang akan dikeluarkan nantinya. Lokasi bank yang semakin jauh akan mengakibatkan semakin besarnya biaya yang diperlukan guna menuju ke bank. Lokasi yang kurang strategis juga akan berdampak pada kurangnya minat dari nasabah guna mempergunakan jasa bank (Kasmir, 2008). Kondisi itu didukung temuan Rachmawati dan Widana (2019) yang menunjukkan bahwa lokasi memberikan pengaruh pada keputusan menjadi nasabah bank syariah secara signifikan. Lokasi bank yang strategis, nyaman, jarak yang dekat, serta mudah ditemukan memiliki pengaruh terhadap keputusan masyarakat untuk menabung. Sementara itu, penelitian Darmawan et al (2019) memperoleh hasil bahwasanya faktor lokasi tidak mempengaruhi keputusan nasabah untuk menabung. Faktor lainnya yang memberikan pengaruh terhadap minat menabung masyarakat pada bank syariah adalah pendapatan dan presepsi bagi hasil. Keynes menjelaskan, besar dari tabungan yang rumah tangga laksanakan bukan tergantung dari tingkatan suku bunga, namun dari tingkatan pendapatan rumah tangga. Semakin besarnya pendapatan seseorang maka semakin besar pula jumlah pendapatan yang ditabung (Harhap, 2016). Hal tersebut didukung penelitian Harhap (2016) yang menemukan bahwasanya pendapatan mempengaruhi minat masyarakat menabung pada bank syariah secara positif. Berbeda halnya pada temuan Febrian (2018) dimana menunjukkan bahwa pendapatan tidak mempengaruhi minat menabung dari masyarakat di bank syariah.

Faktor bagi hasil juga berperan selaku pendorong bagi nasabah yang hendak menabung di bank syariah. Sistem bunga pada perbankan konvensional bisa dikatakan haram dalam syariat Islam, tetapi berbeda dengan bank syariah yang menerapkan sistem bagi hasil yang syariat Islam anjurkan. Profit sharing ataupun bagi hasil yakni pendistribusian pada nasabah akan sejumlah bagian dari keutungan (Harhap, 2016). Banyak dari masyarakat yang masih tidak mengetahui secara tepat sistem yang dipakai bank syariah mengenai bagi hasil. Masyarakat mengasumsikan bahwasanya bagi hasil sama dengan bunga di bank konvensional. Wahyuni (2017) dalam penelitiannya menjelaskan, presepsi bagi hasil dapat meningkatkan minat menjadi nasabah bank syariah. Bisa dikatakan presepsi terkait bagi hasil yang semakin baik akan semakin meningkatkan minat dari masyarakat untuk menjadi nasabah. Namun hal tersebut tidak selaras pada penelitian Andriani (2019) dimana menjelaskan bagi hasil tidak mempengaruhi minat menjadi nasabah di perbankan syariah. 


\section{Metode}

Jenis penelitian ini adalah penelitian kualitatif. Namun dalam penelitian ini peneliti ingin mengubah dari penelitian kualitatif menjadi kuantitatif karena peneilitian ini untuk menguji teori-teori tertentu dengan pengaruh antar variabel, bukan untuk mengetahui makna yang diteliti atau bukan mementingkan prosesnya. Waktu penelitian dimulai pada tanggal 1 Juli 2021 hingga 31 Juli 2021. Teknik pengumpulan data adalah sumber data primer. Untuk memperoleh data-data yang berkaitan dengan masalah yang dibahas, penelitian ini dilakukan dengan menyebarkan kuesioner. Kuesioner cocok digunakan bila jumlah responden cukup besar dan tersebar diwilayah yang luas (Sugiyono, 2013). Peneliti akan memberikan daftar pertanyaan yang telah disusun dan diberikan pada responden untuk mendapatkan jawaban. Peneliti menggunakan kuesioner (angket) yang disebar secara online sehingga tidak membutuhkan kertas. Pengumpulan dan analisis data dibantu dengan Google Form. Pengolahan data adalah suatu proses dalam memperoleh data ringkasan atau angka ringkasan dengan menggunakan cara-cara tertentu. Pengolahan data dalam penelitian ini meliput: (a) Editing yaitu pengecekan atau pengoreksian semua data kuisioner yang telah diisi oleh responden; (b) Coding yaitu pengklasifikasian atau pengelompokan jawaban yang diberikan responden kedalam kategori-kategori tertentu dengan menggunakan simbol-simbol, baik berupa angka maupun huruf; (c) Scoring adalah penentuan atau perhitungan skor jawaban dari responden dengan menggunakan skala likert; dan (d) Tabulating data jawaban responden yang telah sempurna kemudian di kelompokan dengan teliti kemudian dihitung hingga hasilnya berupa sebuah tabel.

Tabel 4

Nilai Skala Likert

\begin{tabular}{lcc}
\hline & Keterangan & Skor \\
\hline Sangat Setuju & 5 \\
Setuju & & 4 \\
Ragu- ragu & & 3 \\
Tidak Setuju & 2 \\
Sangat Tidak Setuju & 1 \\
\hline
\end{tabular}

Sumber: Ghozali (2013)

Variabel dalam penelitian ini yaitu variabel Dependen $(\mathrm{Y})$ dan Variabel Independen $(\mathrm{X})$. Adapun variabel dependen $(\mathrm{Y})$ yaitu minat menabung, sedangkan variabel independen $(\mathrm{X})$ yaitu literasi keuangan $(\mathrm{X} 1)$, kepercayaan (X2), lokasi (X3), pendapatan (X4), persepsi bagi hasil (X5). Penelitian menggunakan Uji validitas, uji yang dilakukan untuk mengukur sah atau tidaknya suatu kuesioner (Ghozali, 2013). Kuesioner dianggap valid apabila pernyataan yang ada di dalam kuesioner mampu mengungkapkan sesuatu yang akan diukur oleh kuesioner tersebut. Uji validitas dapat dilakukan dengan membandingkan $r$ hitung dengan $r$ tabel untuk degree of freedom $(\mathrm{df})=\mathrm{n}-2, \mathrm{n}$ adalah jumlah sampel dan tingkat signifikansi 95\%. Uji Reliabilitas, uji yang digunakan untuk mengukur suatu kuesioner yang merupakan indikator dari variabel atau konstruk (Ghozali, 2013). Suatu kuesioner dapat dikatakan reliabel atau handal apabila instrumen tersebut mampu memberikan jawaban yang konsisten atau stabil dari waktu ke waktu bila kuisioner tersebut diajukan pada responden yang sama. Uji reliabilitas yang digunakan dalam penelitian ini menggunakan Cronbach's Alpha.

Uji normalitas bertujuan untuk menguji apakah variabel pengganggu atau residual dalam model regresi memiliki distribusi yang normal (Ghozali, 2013). Model regresi yang baik yaitu yang memiliki nilai residual yang terdistribusi normal. Normalitas data dapat dilihat menggunakan uji normalitas Kolmogrov-Smirnov.Uji multikoloneritas bertujuan untuk mengetahui apakah model regresi ditemukan adanya korelasi antar variabel independen atau variabel bebas (Ghozali, 2013). Model regresi yang baik seharusnya tidak terjadi korelasi diantara variabel independen. Untuk menguji nilai multikolinearitas dengan melihat nilai VIF (Variance Inflation Factor) dan nilai tolerance dari masing-masing variabel independen terhadap variabel dependen. Uji heteroskedastisitas bertujuan untuk menguji apakah dalam model regresi terjadi perbedaan variance dari residual satu pengamatan ke pengamatan yang lain (Ghozali, 2013). Pengukuran uji heteroskedastisitas dapat menggunakan metode Glejser dalam bantuan SPSS dengan meregresikan semua variabel independen terhadap nilai mutlak residualnya. Penelitian ini menggunakan analisis regresi linier berganda, digunakan untuk menguji dua atau lebih variabel independen terhadap variabel dependen. Adapun model regresi dalam penelitian ini adalah:

$Y=\alpha+\beta_{1} X_{1}+\beta_{2} X_{2}+\beta_{3} X_{3}+\beta_{4} X_{4}+\beta_{5} X_{5}+e$

Keterangan: $Y=$ Minat Menabung; $A=$ Konstanta; $\beta_{1}=$ Koefisien Regresi $X_{1} ; X_{1}=$ Literasi Keuangan; $\beta_{2}=$ Koefisien Regresi $\mathrm{X}_{2} ; \mathrm{X}_{2}=$ Kepercayaan; $\beta_{3}=$ Koefisien Regresi $\mathrm{X}_{3} ; \mathrm{X}_{3}=$ Lokasi' $\beta_{4}=$ Koefisien Regresi $\mathrm{X}_{4} ; \mathrm{X}_{4}=$ Pendapatan; $\mathrm{B}_{5}=$ Koefisien Regresi $\mathrm{X}_{5} ; \mathrm{X}_{5}=$ Presepsi Bagi Hasil; e $=$ Standar Error 
Sodik Dwi Purnomo et al., Analisis Faktor-Faktor yang Mempengaruhi Minat Menabung di Bank Syariah pada Masyarakat Kabupaten Banyumas

\section{Hasil}

Tabel 6.

Profil Responden

\begin{tabular}{|c|c|c|c|}
\hline No & Keterangan & Frekuensi & Presentase \\
\hline & Jenis Kelamin & & \\
\hline 1 & Laki-laki & 24 & $24 \%$ \\
\hline \multirow[t]{2}{*}{2} & Perempuan & 76 & $76 \%$ \\
\hline & Usia & & \\
\hline 1 & $18-25$ Tahun & 74 & $74 \%$ \\
\hline 2 & $26-35$ tahun & 14 & $14 \%$ \\
\hline 3 & $36-45$ tahun & 9 & $9 \%$ \\
\hline \multirow[t]{2}{*}{4} & $>50$ tahun & 3 & $3 \%$ \\
\hline & Pekerjaan & & \\
\hline 1 & Pelajar/Mahasiswa & 25 & $25 \%$ \\
\hline 2 & PNS/Guru/TNI/ Polri & 6 & $6 \%$ \\
\hline 3 & Wiraswasta & 6 & $6 \%$ \\
\hline 4 & Pegawai Swasta & 33 & $33 \%$ \\
\hline \multirow[t]{2}{*}{5} & Lainnya & 30 & $30 \%$ \\
\hline & Penghasilan & & \\
\hline 1 & $<\operatorname{Rp} 1.000 .000$ & 30 & $30 \%$ \\
\hline 2 & Rp $1.000 .000-\operatorname{Rp} 2.000 .000$ & 33 & $33 \%$ \\
\hline 3 & $\operatorname{Rp} 2.000 .000-\operatorname{Rp} 3.000 .000$ & 16 & $16 \%$ \\
\hline \multirow[t]{2}{*}{4} & $>\operatorname{Rp} 3.000 .000$ & 21 & $21 \%$ \\
\hline & Kepemilikan Tabungan Bank Syariah & & \\
\hline 1 & $\mathrm{Ya}$ & 40 & $40 \%$ \\
\hline 2 & Tidak & 60 & $60 \%$ \\
\hline
\end{tabular}

Sumber: Data primer diolah

Pada Tabel 6 di atas menunjukkan bahwa beberapa responden yang akan diteliti paling besar didominasi oleh perempuan, dan untuk usia didominasi oleh responden yang berusia $18-25$ tahun. Adapun pekerjaan responden paling banyak adalah seorang pelajar/mahasiswa. Dari 100 responden, 33 orang memiliki penghasilan antara Rp 1juta - Rp 2juta, dan dari 100 responden 60 responden tidak memiliki tabungan di bank syariah.

Tabel 7.

Hasil Uji Validitas Literasi Keuangan $\left(\mathbf{X}_{1}\right)$

\begin{tabular}{|c|c|c|c|c|}
\hline No & Item & r hitung & r tabel & Keterangan \\
\hline & Literasi Keuangan (X1) & & & \\
\hline 1 & $\mathrm{X} 1.1$ & 0,502 & 0,1946 & Valid \\
\hline 2 & $\mathrm{X} 1.2$ & 0,666 & 0,1946 & Valid \\
\hline 3 & $\mathrm{X} 1.3$ & 0,639 & 0,1946 & Valid \\
\hline 4 & $\mathrm{X} 1.4$ & 0,633 & 0,1946 & Valid \\
\hline 5 & $\mathrm{X} 1.5$ & 0,711 & 0,1946 & Valid \\
\hline \multirow[t]{2}{*}{6} & X1.6 & 0,558 & 0,1946 & Valid \\
\hline & Kepercayaan (X2) & & & \\
\hline 1 & $\mathrm{X} 2.1$ & 0,791 & 0,1946 & Valid \\
\hline 2 & $\mathrm{X} 2.2$ & 0,811 & 0,1946 & Valid \\
\hline 3 & $\mathrm{X} 2.3$ & 0,742 & 0,1946 & Valid \\
\hline \multirow[t]{2}{*}{4} & $\mathrm{X} 2.4$ & 0,755 & 0,1946 & Valid \\
\hline & Lokasi (X3) & & & \\
\hline 1 & X3.1 & 0,891 & 0,1946 & Valid \\
\hline 2 & X3.2 & 0,883 & 0,1946 & Valid \\
\hline \multirow[t]{2}{*}{3} & X3.3 & 0,769 & 0,1946 & Valid \\
\hline & Pendapatan (X4) & & & \\
\hline 1 & $\mathrm{X} 4.1$ & 0,542 & 0,1946 & Valid \\
\hline 2 & $\mathrm{X} 4.2$ & 0,359 & 0,1946 & Valid \\
\hline 3 & X4.3 & 0,823 & 0,1946 & Valid \\
\hline \multirow[t]{2}{*}{4} & $\mathrm{X} 4.4$ & 0,636 & 0,1946 & Valid \\
\hline & Presepsi Bagi Hasil (X5) & & & \\
\hline 1 & X5.1 & 0,813 & 0,1946 & Valid \\
\hline 2 & X5.2 & 0,749 & 0,1946 & Valid \\
\hline
\end{tabular}


Sodik Dwi Purnomo et al., Analisis Faktor-Faktor yang Mempengaruhi Minat Menabung di Bank Syariah pada Masyarakat Kabupaten Banyumas

\begin{tabular}{|c|c|c|c|c|}
\hline 3 & X5.3 & 0,656 & 0,1946 & Valid \\
\hline 4 & X5.4 & 0,804 & 0,1946 & Valid \\
\hline \multirow[t]{2}{*}{5} & $\mathrm{X} 5.5$ & 0,712 & 0,1946 & Valid \\
\hline & Minat Menabung (Y) & & & \\
\hline 1 & Y.1 & 0,725 & 0,1946 & Valid \\
\hline 2 & Y.2 & 0,825 & 0,1946 & Valid \\
\hline 3 & Y.3 & 0,774 & 0,1946 & Valid \\
\hline 4 & Y.4 & 0,823 & 0,1946 & Valid \\
\hline 5 & Y.5 & 0,844 & 0,1946 & Valid \\
\hline 6 & Y.6 & 0,612 & 0,1946 & Valid \\
\hline 7 & Y.7 & 0,810 & 0,1946 & Valid \\
\hline 8 & Y.8 & 0,616 & 0,1946 & Valid \\
\hline 9 & Y.9 & 0,862 & 0,1946 & Valid \\
\hline
\end{tabular}

Sumber : Data primer yang diolah, 2021

Tabel 7 dapat diketahui bahwa nilai $r$ hitung pada seluruh pertanyaan dari seluruh variabel memiliki nilai lebih besar dari $r$ tabel. Dengan demikian, seluruh pernyataan pada variabel X1, X2, X3, X4, X5, dan Y dinyatakan valid. Adapun Uji Reliabilitas dilakukan untuk melihat sejauh mana hasil pengukuran dapat dipercaya. Hasil suatu pengukuran dapat dipercaya apabila dalam beberapa kali pelaksanaan pengukuran terhadap suatu subjek yang sama diperoleh hasil yang relatif sama artinya mempunyai konsistensi pengukuran yang baik . Nilai reliabilitas bisa dilihat dari nilai Cronbach Alpa. Reliabiltas yang tinggi ditunjukkan dengan nilai cronbach alpa 1,00 dan nilai reliabilitas dianggap sudah cukup memuaskan atau tinggi jika nilai cronbach alpa $>0,70$,

Tabel 8.

Hasil Uji Reliabilitas

\begin{tabular}{llcl}
\hline No & \multicolumn{1}{c}{ Variabel } & Cronbach's Alpha & Keterangan \\
\hline 1 & Literasi Keuangan (X1) & 0,747 & Reliabel \\
2 & Kepercayaan (X2) & 0,805 & Reliabel \\
3 & Lokasi (X3) & 0,824 & Reliabel \\
4 & Pendapatan (X4) & 0,702 & Reliabel \\
5 & Presepsi Bagi Hasil (X5) & 0,792 & Reliabel \\
6 & Minat Menabung (Y) & 0,781 & Reliabel \\
\hline
\end{tabular}

Sumber: Data primer diolah, 2021

Tabel 8 dapat diketahui bahwa nilai Cronbach's Alpha pada variabel Literasi Keuangan $\left(\mathrm{X}_{1}\right)$, Kepercayaan $\left(\mathrm{X}_{2}\right)$, Lokasi $\left(\mathrm{X}_{3}\right)$, Pendapatan $\left(\mathrm{X}_{4}\right)$, Presepsi Bagi Hasil $\left(\mathrm{X}_{5}\right)$, Minat Menabung (Y) lebih besar dari 0,70 maka dapat disimpulkan bahwa semua pernyataan pada kuesioner dalam penelitian ini dinyatakan reliabel.

Tabel 9.

Hasil Regresi Linear Berganda

\begin{tabular}{|c|c|c|}
\hline Variabel & Koefisien & Probabilitas \\
\hline Constant & 2.885 & \\
\hline Literasi Keuangan (X1) & 0.208 & 0.172 \\
\hline Kepercayaan (X2) & 0.647 & 0.002 \\
\hline Lokasi (X3) & 0.144 & 0.489 \\
\hline Pendapatan (X4) & 0.297 & 0.084 \\
\hline Presepsi Bagi Hasil (X5) & 0.625 & 0.001 \\
\hline F hitung & 30.706 & 0,0000 \\
\hline Koefisien Determinasi $\left(\mathrm{R}^{2}\right)$ & 0,600 & \\
\hline
\end{tabular}

Sumber: Olahan data

Pengaruh literasi keuangan terhadap minat menabung di bank syariah.

Literasi keuangan tidak berpengaruh signifikan terhadap minat menabung di bank syariah pada masyarakat Kabupaten Banyumas. Hasil penelitian ini tidak sejalan dengan penelitian yang telah dilakukan oleh Fauzi (2020) dan Rozikin \& Solekhah (2020) yang menyatakan literasi keuangan berpengaruh positif dan signifikan terhadap minat menabung di bank syariah. Hasil penelitian ini sejalan dengan penelitian Hakim (2020) dimana literasi keuangan tidak berpengaruh terhadap minat menabung di bank syariah. Hal ini dikarenakan responden tidak memandang literasi keuangan sebagai faktor utama dalam menentukan keputusan untuk menabung di bank syariah. Pemahaman literasi keuangan yang rendah didasari oleh asumsi masyarakat mengenai operasional lembaga bank syariah sama dengan 
bank konvensional. Kurangnya sosialisasi tentang produk-produk perbankan syariah kepada masyarakat sehingga masih banyak masyarakat yang belum tahu secara detail produk-produk yang ada di perbankan syariah. Pada penelitian ini faktor literasi keuangan akan memiliki pengaruh apabila didukung oleh faktor lain seperti kepercayaan responden dan faktor pendapatan responden. Peneliti beranggapan bahwa faktor pendapatan masih menjadi faktor utama oleh responden dalam menentukan minat untuk menabung di bank syariah.

\section{Pengaruh kepercayaan terhadap minat menabung di bank syariah}

Kepercayaan berpengaruh positif dan signifikan terhadap minat menabung di bank syariah pada masyarakat Kabupaten Banyumas. Jadi semakin tinggi rasa percaya yang dimiliki masyarakat terhadap bank syariah maka minat menabung masyarakat di bank syariah juga meningkat. Kepercayaan masyarakat pada pihak bank bahwa bank dapat mengelola uangnya dan pelayanan yang diberikan oleh pegawai bank syariah menunjukkan bahwa pengaruh kepercayaan dapat meningkatkan minat menjadi nasabah bank syariah. Hasil penelitian ini sejalan dengan penelitian yang telah dilakukan oleh Andriani \& Halmawati (2019) dan Ltifi et al (2016) yang menyatakan bahwa kepercayaan berpengaruh postif dan signifikan terhadap minat menabung di bank syariah. Artinya bahwa apabila kepercayaan masyarakat semakin meningkat terhadap bank syariah maka minat menabung di bank syariah juga akan meningkat.

\section{Pengaruh lokasi terhadap minat menabung di bank syariah}

Lokasi tidak berpengaruh signifikan terhadap minat menabung di bank syariah pada masyarakat Kabupaten Banyumas. Hasil penelitian ini tidak sejalan dengan penelitian yang telah dilakukan oleh Rachmawati \& Widana (2019) yang menyatakan lokasi berpengaruh signifikan terhadap minat menabung di bank syariah. Namun hasil penilitian ini sejalan dengan penelitian yang telah dilakukan oleh Darmawan et al (2019) yang menyatakan lokasi tidak berpengaruh terhadap minat menabung di bank syariah. Lokasi bank yang mudah diaskes, dekat jalan rasa, dan mudah dijangkau dengan transportasi menjadi salah satu pertimbangan yang diambil oleh masyarakat dalam menabung. Pada penelitian ini lokasi tidak berpengaruh terhadap minat menabung masyarakat di bank syariah karena cukup banyak masyarakat yang bertempat tinggal jauh dari bank syariah, sehingga lokasi bukan faktor yang mempengaruhi nasabah berminat menabung di bank syariah.

\section{Pengaruh pendapatan terhadap minat menabung di bank syariah}

Pendapatan berpengaruh positif terhadap minat menabung di bank syariah pada masyarakat Kabupaten Banyumas. Jadi semakin tinggi pendapatan seseorang maka minat menabung masyarakat di bank syariah juga meningkat. Penelitian ini tidak sejalan dengan penelitian yang telah dilakukan oleh Febrian (2018) yang menyatakan pendapatan tidak berpengaruh signifikan terhadap minat menabung di bank syariah. Namun penelitian ini sejalan dengan penelitian yang dilakukan oleh Harhap (2016), Sen et al (2020) yang menyatakan pendapatan berpengaruh terhadap minat menabung di bank syariah. Menurut teori Keynes, menyatakan bahwa konsumsi dipengaruhi oleh pendapatan disposibel. Pendapatan disposibel merupakan pendapatan yang tidak habis dikonsumsi, sehingga sisa pendapatan tersebut ditabung. Secara tidak langsung tabungan masyarakat dipengaruhi oleh besarnya pendapatan dan besarnya konsumsi. Artinya ketika masyarakat mempunyai pendapatan yang semakin tinggi maka mereka akan meningkatkan minat menabung di bank syariah karena mereka akan meresa aman menyimpan uangnya di bank syariah.

\section{Pengaruh presepsi bagi hasil terhadap minat menabung di bank syariah}

Presepsi bagi hasil berpengaruh positif dan signifikan terhadap minat menabung di bank syariah pada masyarakat Kabupaten Banyumas. Sistem bagi hasil yang sesuai dengan syariah menjauhi riba dan masyarakat menganggap bahwa bagi hasil lebih adil dan menguntungkan semua pihak menyebabkan masyarakat lebih berminat menabung di bank syariah. Jadi semakin tinggi presepsi bagi hasil maka minat menabung masyarakat di bank syariah juga meningkat. Perkembangan bank syariah yang masih kurang baik menyebabkan kurangnya presepsi masyarakat yang masih beranggapan bahwa sistem bunga pada bank konvensional sama dengan bank syariah. Istilah bunga dalam bank syariah tidak digunakan akan tetapi menggunakan istilah bagi hasil. Nasabah berminat untuk menyimpan uangnya di bank syariah karena presepsi masyarakat yang ingin mendapatkan bunga sesuai dengan anjuran Islam. Hasil dalam penelitian ini bertentangan dengan penelitian yang dilakukan oleh Andriani \& Halmawati (2019), yang menyatakan presepsi bagi hasil tidak berpengaruh terhadap minat menabung di bank syariah. Namun hasil dalam penelitian ini sejalan dengan penelitian yang telah dilakukan oleh Febrian (2018), dan Wahyuni (2017) yang membuktikan bahwa presepsi bagi hasil berpengaruh dan signifikan terhadap minat menabung masyarakat di bank syariah. 


\section{Simpulan}

Berdasarkan hasil penelitian dan pembahasan dapat disimpulkan literasi keuangan dan lokasi tidak berpengaruh terhadap minat menabung di bank syariah pada masyarakat Kabupaten Banyumas. Sedangkan variabel kepercayaan, pendapatan dan presepsi bagi hasil berpengaruh terhadap minat menabung di bank syariah pada masyarakat Kabupaten Banyumas. Penelitian ini memiliki implikasi bagi bank syariah perlunya meningkatkan pemberian informasi tentang bank syariah seperti prinsip syariah dan produk yang ada di bank syariah sehingga minat menabung di bank syariah meningkat.

\section{Daftar Pustaka}

Alhamid, T. (2019). Perkembangan Perbankan Syariah (2009-2018) di Indonesia dan Sumber Daya Manusianya. (10), $1-5$.

Amdar, S. (2016). Pengaruh Jumlah Penduduk Muslim, Pembiayaan, dan Bagi Hasil Terhadap Jumlah Nominal Tabungan Nasabah Pada Bank Syariah di Indonesia. E-Journal Unsrat, 5(2), 249-259.

Andriani, G. F. (2019). Pengaruh Bagi Hasil, Kelompok Acuan, Kepercayaan dan Budaya Terhadap Minat Menjadi Nasabah Bank Syariah. Jurnal Eksplorasi Akuntansi, 1(3), 1322-1336.

Darmawan, A., Indahsari, N.D., Rejeki, S., Aris, M.R., Yasin, R. (2019). Analisis Faktor-Faktor yang Mempengaruhi Minat Nasabah Menabung di Bank Jateng Syariah. Journal Fokus Bisnis, 18(1).

Fauzi, A. (2020). Pengaruh Religiusitas Dan Literasi Keuangan Syariah Mahasiswa Terhadap Minat Menjadi Nasabah Di Bank Syariah. Economic Education Analysis Journal, 9(2), 473-486.

Fauzi, R. N. (2020). Pengaruh Literasi Keuangan Syariah, Pengetahuan Agama, dan Promosi Terhadap Minat Menjadi Nasabah Bank Syariah (Studi Kasus pada Mahasiswa Santri di Kabupaten Sleman Yogyakarta). Jurnal Pendidikan Dan Ekonomi, 9(1), 37-46.

Febrian, W. D. (2018). Analisis Pendapatan Masyarakat dan Bagi Hasil (Mudharabah) Terdahap Minat Masyarakat Menabung Pada PT. Bank Muamalat Indoneisa TBK Cabang Pekanbaru. Jurnal Rumpun Ekonom Syariah, 1(2), 111-128.

Ghozali, I. (2013). Aplikasi Analisis Multivariate dengan Program IBM SPSS 21 Update PLS Regresi. Semarang: Badan Penerbit Universitas Diponogoro.

Hakim, M. A. R. (2020). Analisis Pengaruh Literasi Keuangan Syariah Terhadap Keputusan Membuka Rekening Bank Syariah (Studi Pada Mahasiswa Islam Kota Malang). Jurnal Ekonomi.

Harhap, R. S. P. (2016). Faktor-faktor Yang Mempengaruhi Minat Nasabah Menabung. Jurnal Al-Qasd, 1(1), 21-39.

Kasmir, (2008). Bank dan Lembaga Keuangan Lainnya. Jakarta: PT. Raja Grafindo Persada.

Ltifi, M., Hikkerova, L., Aliouat,B., \& Gharbi, J. (2016). The Determinants of The Choice of Islamic Banks in Tunisia. International Journal of Bank Marketing, 34(5), 710-730.

Marlina, N. dan Iskandar, D. 2019. Gerakan Menabung Sejak Dini di Rowosari. Jurnal Pengabdian Vokasi. 01 (01), $27-32$.

Otoritas Jasa Keuangan. (2020). Statistik Perbankan Syariah - Oktober 2020. Dipetik Desember 2020, dari OJK Website: ojk.go.id

Rahma, A. (2020). Tantangan Besar Kembangkan Perbankan Syariah, Literasi dan Jaringan, https://www.liputan6.com/bisnis/read/4365809/tantangan-besar-kembangkan-perbankan-syariah-literasi-danjaringan. Diakses tanggal 15 November 2020.

Rachmawati, A. \& Widana, G.O. (2019). Pengaruh Consumer Knowledge, Brand Image, Religiusitas, dan Lokasi terhadap Keputusan Menjadi Nasabah Pasa Bank Syariah. Jurnal Liquidity, 8(2), 111-123.

Rozikin, A. Z., \& Sholekhah, I. (2020). Islamic Financial Literacy, Promotion, and Brand Image Towards Saving Intention in Sharia Bank. Iqtishadia, 13(1), 95.

Sen, S., Antara, N., \& Sen, S. (2020). The Determinans Of Opening Account With Islamic Banks. Journal of Islamic Marketing,

Sugiyono, P. D. (2013). Metode Penelitian Kuantitatif, Kualitatif,dan R\&D. Bandung : Alfabeta, Cv.

Wahyuni, S. (2017). Pengaruh Presepsi Kualitas Pelayanan dan Bagi Hasil Terhadap Minat Masyarakat Mejadi Nasabah Bank Syariah. Jurnal Akuntansi Dan Manajemen, 2(2), 437-459. 